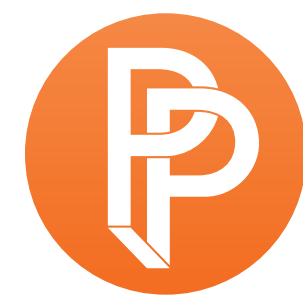

PERFORMANCE

PHILOSOPHY

\title{
SITES OF APPEARANCE, MATTERS OF THOUGHT: HANNAH ARENDT AND PERFORMANCE PHILOSOPHY
}

\section{DIANA DAMIAN MARTIN THE ROYAL CENTRAL SCHOOL OF SPEECH AND DRAMA THERON SCHMIDT UNSW SYDNEY}

This special issue of Performance Philosophy examines the thresholds, borders, and dialogues between Hannah Arendt's work and performance philosophy, bringing together contributions that investigate political resistance, thought, and practice. In our call for papers, we began with a provocation: we live in Arendtian times. Though it would give her no comfort to know it, Arendt's 1951 The Origins of Totalitarianism has been in near constant citation during this period of strongman politics and resurgent ethnic nationalism. After the 2016 US election, it was reportedly out-ofstock on Amazon (Griswold 2017), and Arendt scholar Roger Berkowitz (2017) provides a thorough analysis of its relevance to alt-right politics and the rise of Donald Trump (see also Bernstein 2018). Meanwhile, her diagnosis of the predicament of those fleeing persecution and abandoning their countries of birth —as she herself did ("We Refugees" [1943] 1994) - remains all too relevant with regard to the deprivation of legal status to refugees. As Arendt pointed out, refugees continue to lack the rights that are recognised even for those who have broken the law, but are instead outside the law (Arendt [1951] 1973, 267-302), and her discussion of 'the right to have rights' prefigures recent analyses by Agamben (1995, 2005), Rancière (2004), Gündogdu (2015), and others.

Arendt's life-long inquiry into the nature of political experience and rule asks questions not only about the process of thinking and the condition of plurality, but also about appearance, freedom, dissent, and authority. In her thinking from and with history, her engagement with the realms of the social and political, and her probing questions of authority and legislation as much as those of sensing, togetherness, and citizenship, Arendt's work provides a point of entry to thinking through and on appearance as a political problem, and thinking as a problem of appearance. 
In this issue, we foreground Arendt's position on thinking as a kind of seizing, a searching for what is beyond its reach, and beyond what is already in appearance (Arendt 1971). This provocation also implicates a wilful decision to orient attention not only to Arendt's body of work, but also to entanglements that this makes manifest: human and non-human, thinking and action, appearance and absence, and public and private. As a thinker moving between ecologies of knowledge, Arendt advocated a philosophy that was actively engaged in the world-sometimes described as a 'hermeneutic phenomenology' (Borren 2013). At the same time, Arendt was sceptical of disciplinary labels, and committed to praxis as a political, and hence civic responsibility: "No theories. Forget all theories," were reportedly her first words to her students (Arendt 2009, xxii).

As a public thinker, Arendt gained widespread attention for the way in which she chose to bear witness to the Eichmann trial (Arendt [1963] 2006); and she kept an intellectual diary, her Denktagebuch, as an extraordinary document of her intellectual journey through her life (see Storey and Berkowitz 2017). Her work on thinking as always 'out of order', 'interrupting all other activities' (Arendt 1971, 82), and her unfinished examination of judgment, offer a resistant poiesis of reflection and praxis, whereby critique is an embodied operation of withdrawal, action and appearance. Arendt's work has also inspired artistic and activist interventions: in 2015, for example, Tania Bruguera launched the Hannah Arendt International Institute for Artivism in Havana with a hundred-hour reading of The Origins of Totalitarianism. Arendt's philosophy is an activist philosophy, in which thinking and doing are inseparable.

Arendt's conception of politics is what we might call a performative politics, based on 'action'. Rather than restricting politics to the operations of coercion and brute force, or a politics oriented toward certain ends, Arendt was interested in 'spaces of appearance', which 'come into being whenever [people] are together in the manner of speech and action, and therefore predates and precedes all formal constitution of the public realm and the various forms of government' (Arendt [1958] 1998, 199). This Arendtian performative politics is also one predicated on a gentle conflict, a 'warfare between thought and common sense' (Arendt 1971, 92)—one with contentious differentiations between the social and the political, but also one where thought and collectivity are necessarily embroiled. This conflict shaped Arendt's presence as a woman working in political philosophy, whose place in intersectional debates on democracy, citizenship, and the politics of exclusion remains an ongoing debate (Pitkin 1981, Young-Bruehl 1982, Dietz 2002), offering a poetics of the publicness of political life.

Arendt's influence on contemporary political philosophy can be seen everywhere, whether explicitly acknowledged or not: in Chantal Mouffe's distinction between politics and 'the political' (Mouffe 2000, 20); in Jacques Rancière's idea of the 'partition of the sensible' and matters of appearance, in which '[p]olitics, before all else, is an intervention in the visible and the sayable' (Rancière 2009, 13); in Jean-Luc Nancy's account of 'co-appearance' or 'compearance' (Nancy [1986] 1991) and the plurality of being (Nancy [1996] 2000); in Giorgio Agamben's biopolitics (Agamben 1998); in Wendy Brown's investigation of neoliberalism's undoing of the demos (Brown 2015); and in Judith Butler's explicit invocation of Arendt in relation to the 'movement of the squares' and arguments for agency in plurality (Butler and Athanasiou 2013; Butler 2015). Whereas Arendt 
herself focused perhaps too much on an idealised view of the Greek polis (Euben 2000), a performance philosophy might ask where and how these spaces of appearance can emerge, and in what ways performance can be a modus of thinking the political in Arendtian philosophy.

This issue begins with Margaret Werry asking 'What's Left of Rights?' in the wake of numerous philosophical critiques of the Western rights-bearing subject, as well the ongoing historical failings of the category and instruments of human rights. But in events such as the 2017 Whanganui settlement, in which the parliament of Aotearoa New Zealand granted personhood to the Whanganui river and acknowledged a new collective entity, Te Awa Tupua, Werry sees the emergence of a post-human rights that are not tied to a sovereign, autonomous subject. While such a view needs no justification within Māori cosmology, it radically refigures Western rights discourse, and Werry offers a 'perverse, post-human, and even queer return' to Arendt's thinking, arguing that Arendt's commitment to 'vitality' in reimagining foundations of human rights can be the basis for a reading of 'Arendt the ecologist'-a view that invigorates performance with a nonhuman political capacity.

Arendt's work in The Human Condition introduced key concepts such as 'action' and 'appearance'but what kind of action is thinking? This is the question at the heart of Arendt's later work The Life of the Mind, to which Diana Damian Martin returns, drawing on Arendt's suggestion that thinking itself is dangerous $(1971,76)$. Whereas Arendt tends to figure thinking as withdrawal into a private domain, as opposed to the publicness of action, Damian Martin draws on more recent affect theory to explore the porosity of private and public and to re-position this withdrawal as interruption. Damian Martin is particularly interested in this as a model for what she calls 'nonconforming criticism' as an activity that is not based on the application and affirmation of existing knowledge and values, but instead an embodied, vulnerable, uncertain process, 'a way of making appear'. In her encounter with Wassily Kandinsky's abstraction of a series of postures of German Expressionist choreographer Gret Palucca, based on photographs by Charlotte Rudolph, Damian Martin tracks her own slipping attention as a form of unfinished thought and a 'hopeful dazzlement'.

This question of Arendt's, 'what is the difference between thinking and doing?', is also the question that is randomly drawn as the starting point for Think We Must (2017), a year-long "'thinktanking" performance' by Panopoly Performance Laboratory. As one of the participants in this project, Esther Neff examines the Arendtian relation of thinking and doing in the context of feminist and anti-colonial political discourse-not just as abstract concepts, but as practical questions that informed the working of the thinktank itself: 'how can this/a (p)articular assembly intentionally perform thinking actions that do something?', they ask themselves.

Inspired by the ongoing actions of The Institute for Precarious Consciousness, Cory Tamler also enquires into modes of collective gathering, with particular attention to the legacy of feminist consciousness-raising. Understanding anxiety as 'the dominant affect of neoliberal capitalism', Tamler argues that alienation-a familiar strategy of politically-engaged theatre-holds potential 
for an interrogation of anxiety as political phenomenology, generating a mobilising rather than isolating affect. Tamler reads Arendtian conceptions of public and private, and thought and action, in relation to queer phenomenology and Brechtian alienation, making a case for a reparative practice through the deployment of an alternative politics of anxiety.

Continuing the thread of re-reading Arendt in relation to the micropolitics of affect, Leonie Persyn focuses on the specific moment of hesitation that we experience in each and every living moment, the moment of 'non-breath' between inhalation and exhalation (and vice versa), as a repeated instance of Arendt's idea of natality. Persyn suggests that we might map Arendt's schema of the phases of action onto the sequence of movements that make up a breath; and more than this, that breath might become analogous to a speaking action, a gesture of intimacy between actor and spectator, as illustrated in the choreography of Kinga Jaczewska. And in the films of Chantal Akerman, Persyn sees the motif of breathing as a site of conflict and negotiation between private and public worlds.

Arendt's influential idea of 'spaces of appearance', the temporary sites of politics that erupt through public speech and action, is a shared point of departure for articles by Sevi Bayraktar and Luke Matthews. Bayraktar draws on extensive interviews and field work in Istanbul to address the ways in which Turkish activists create 'choreographies of dissent' in response to the restrictions on public assembly and dissenting speech imposed by the government of Recep Tayyip Erdoğan. Whereas the state implements a strategy of forced dispersal, prohibiting gathering in central spaces such as Taksim Square, Bayraktar argues that activists re-deploy dispersal as a counter-tactic, mobilising temporary, transient spaces as sites of political action; and moreover, they appropriate and re-use traditional folk-dance structures for a 'choreopolitics' of pluralism and solidarity. Noting Arendt's ambivalent (and sometimes contradictory) deployment of the idea of the theatre as a model of public action, Matthews presents Heiner Goebbels's self-described 'theatre of absence' as a possible political theatre, one founded not in representational politics but in creating conditions of spontaneity, plurality, and appearance. Across many of Goebbels's works, but in particular his 'noman-show' Stifters Dinge (2007), Matthews identifies an 'empty centre' that permits a 'freedom of perception'-and indeed a source of pleasure in that freedom.

Finally, this collection on Arendt concludes with an engagement not just with Arendt's ideas, but with the life of Arendt herself-or at least 'putatively' so. In Miriam Shenitzer's exhibition of fauxartefacts from Arendt's life, Michael Zank finds a vivid manifestation of the fragmentation of collective history that characterises the twentieth century. In the disappearance of the 'real' Arendt amidst this fabricated collection of anecdote and biographical remnants, the past 'remains' (as Rebecca Schneider argues), but as an ethical call to our own remembrance.

This issue of Performance Philosophy also includes two additions to our recurring sections, [Margins] and ReViews. Although not connected to the reflections on Arendt, these articles share with all the contributors to this volume an interest in a politically informed performance, and the 
performativity of politics, that allows for an expanded openness to who or what counts as politics, and a resistance to forces that would foreclose on the possibility of action.

[Margins] was imagined and created by editor Kélina Gotman as a space within the academic journal for creative, non-standard approaches to writing and works for the (digital) page. This issue marks Gotman's final contribution as editor, as she is handing over responsibility for this section, in the form of a provocation from Meghan Moe Beitiks. Drawing on her experience as an artist, facilitator, and audience-member, Beitiks wonders what it might mean to think of facilitation as a life practice that can be extrapolated from the artistic realm to address the fundamental need 'to be heard and understood'-a need that might extend to nonhuman actors and inanimate matter. Her work addresses itself to a series of tables: activated in performance, as a surface for other objects, or even as an object of interest for a curious bull.

The ReViews section, edited by Will Daddario and loana Jucan, invites contributors to engage with a work or event that they have already encountered at least one before in the course of their lives, and in this issue, Josh Widera revisits a work that he experienced particularly very in his life indeed: Bartholomew and the Oobleck by children's author Dr. Seuss. In the Seuss story, oobleck is a green goo that falls from the sky and sticks to everything, literally clogging up the daily operations of its imaginary kingdom. In our world, oobleck is also one of the names given to a mixture of cornstarch and water that is simple to make, but complex in its behaviour: a non-Newtonian fluid that behaves like a liquid or solid depending on the energy with which one interacts with it, such that slowmoving objects can be absorbed, but a quick blow will be repelled. Drawing on contemporary thinkers of plasticity and resistance, Widera advocates for 'becoming oobleck' as political strategy, 'a recipe to simultaneously absorb care and reject force'.

As contributors to this special issue have examined, Arendt's body of work, and its implications for phenomenology, governmentality, rights, and ecology, offer productive ways through which to consider a praxis that is performative, but also iterative and affective. Arendt's body of work is a thinking in motion, imbued with a political poetics that continues to invite, perhaps in equal measure, inquiry and speculation. Arendt's is a thinking for, as much as of the political; but it is also a thinking that is inherently connected to vitality, theatricality, and publicness. For performance philosophy, the challenge remains to consider what constitutes an irreversible action, and what conditions frame a political event. What does spectatorship offer as a paradigm through which to understand the relation of the civic to the collective? What might vitality contribute to an anticolonial and anti-racist political praxis? In what ways does Arendtian thought translate to questions of post and non-human political ethics, judgment, and thinking? If, in Arendtian terms, thinking itself is dangerous, then perhaps we need to continue to occupy the edges of thought, where it is not yet formed, and where action is just beginning to take shape-in other words, the conjunction of performance and philosophy, in all their entanglements. 


\section{Works Cited}

Agamben, Giorgio. 1995. "We Refugees." Symposium: A Quarterly Journal in Modern Literatures 49 (2): 114-19. https://doi.org/10.1080/00397709.1995.10733798

_-_. 1998. Homo Sacer: Sovereign Power and Bare Life. Translated by Daniel Heller-Roazen. Stanford: Stanford University Press.

_-_. 2005. State of Exception. Translated by Kevin Attell. Chicago: University of Chicago Press. https://doi.org/10.7208/chicago/9780226009261.001.0001

Arendt, Hannah. (1943) 1994. "We Refugees." In Altogether Elsewhere: Writers On Exile, edited by Marc Robinson, 110-19. London: Faber and Faber.

(1951) 1973. The Origins of Totalitarianism. New York: Harvest/HBJ.

. (1958) 1998. The Human Condition. 2nd ed. Chicago: University of Chicago Press.

. (1963) 2006. Eichmann in Jerusalem: A Report on the Banality of Evil. New York: Penguin Classics.

. 1971. The Life of the Mind: Thinking. London: Secker \& Warburg.

2009. The Promise of Politics. Edited by Jerome Kohn. New York: Schocken.

Berkowitz, Roger. 2017. "Why Arendt Matters: Revisiting 'The Origins of Totalitarianism."' Los Angeles Review of Books, March 19. https://lareviewofbooks.org/article/arendt-matters-revisiting-origins-totalitarianism/.

Bernstein, Richard J. 2018. Why Read Hannah Arendt Now. Cambridge: Polity.

Borren, Marieke. 2013. "'A Sense of the World': Hannah Arendt's Hermeneutic Phenomenology of Common Sense." International Journal of Philosophical Studies 21 (2): 225-55.

https://doi.org/10.1080/09672559.2012.743156

Brown, Wendy. 2013. Undoing the Demos: Neoliberalism's Stealth Revolution. London: Zone.

Butler, Judith. 2015. Notes Toward a Performative Theory of Assembly. Cambridge, MA: Harvard University Press. https://doi.org/10.4159/9780674495548

Butler, Judith, and Athena Athanasiou. 2013. Dispossession: The Performative in the Political. Cambridge: Polity.

Dietz, Mary. 2002. Turning Operations: Feminism, Arendt, Politics. London: Routledge.

Euben, J. Peter. 2000. "Arendt's Hellenism." In The Cambridge Companion to Hannah Arendt, edited by Dana Villa, 151-64. Cambridge: Cambridge University Press. https://doi.org/10.1017/CCOL0521641985.008

Griswold, Alison. 2017. "'The Origins of Totalitarianism,' Hannah Arendt's Definitive Guide to Tyranny, Has Sold out on Amazon." Quartz, January 30. https://qz.com/897517/the-origins-of-totalitarianism-hannah-arendtsdefining-work-on-tyranny-is-out-of-stock-on-amazon/.

Gündogdu, Ayten. 2015. Rightlessness in an Age of Rights: Hannah Arendt and the Contemporary Struggles of Migrants. Oxford: Oxford University Press.

Mouffe, Chantal. 2000. The Democratic Paradox. London: Verso.

Nancy, Jean-Luc. (1986) 1991. The Inoperative Community. Translated by Peter Connor. Minneapolis: University of Minnesota Press.

_-_. (1996) 2000. Being Singular Plural. Translated by Robert D. Richardson. Stanford: Stanford University Press.

Pitkin, Hanna Fenichel. 1981. "Justice: On Relating Private and Public." Political Theory 9 (3): $327-52$. https://doi.org/10.1177/009059178100900304

Rancière, Jacques. 2004. "Who Is the Subject of the Rights of Man?" South Atlantic Quarterly 103 (2/3): 297-310. https://doi.org/10.1215/00382876-103-2-3-297

2009. Dissensus: On Politics and Aesthetics. Translated by Steven Corcoran. London: Continuum. 
Storey, Ian, and Roger Berkowitz, eds. 2017. Artifacts of Thinking: Reading Hannah Arendt's Denktagebuch. New York: Fordham University.

\section{Biographies}

Diana Damian Martin is a writer and researcher working at the intersection between performance and politics. She is a Senior Lecturer in Performance Arts at the Royal Central School of Speech and Drama, member of practice research committee Generative Constraints, and co-hosts Critical Interruptions, Something Other, and The Department of Feminist Conversations.

Theron Schmidt is a writer, teacher, and artist, currently living and working on unceded Gadigal land. He has published widely on contemporary theatre and performance, participatory art practices, and politically engaged performance. He is a founding co-convener the Performance Philosophy network, co-editor of Performance Philosophy, and associate editor of Performance Research. He also makes performance as a solo and collaborative artist.

(C) 2019 Diana Damian Martin and Theron Schmidt

(c) (1) Except where otherwise noted, this work is licensed under a Creative Commons Attribution-

(cc) Non Commercial-ShareAlike 4.0 International License. 